THURSDAY, SEPTEMBER 9, r9I5.

\section{SOLAR MYTHS.}

Sun Lore of All Ages. A Collection of Myths and Legends Concerning the Sun and Its Worship: By W. T. Olcott. Pp. xiii +346 . (New York and London: G. P. Putnam's Sons, rgr4.) Price Ios. $6 d$. net.

T the preface it is stated that the author, during the compilation of a volume on "Star Lore of All Ages," found a wealth of interesting material pertaining to the mythology and folk-lore of the sun which seemed worth putting together in a separate volume, including the legends, traditions and superstitions which all ages and nations have woven about the sun.

The author seems to have gathered his materials from a number of works on mythology and folklore, from which he frequently gives verbatim extracts. Outside this subject he does not appear to have made any special study of the general rise and progress of civilisation, as he sometimes makes curious mistakes. For instance, he tells us (p. r37) that Anaxagoras was put to death on account of his scientific opinions. But a worse fault is that no attempt is made to systematise the immense amount of legends and stories he has collected. The reader is repeatedly carried from India to North America, thence to Finland and via Greece to Scandinavia and back again. And the author has not avoided the snare in which so many students of folk-lore have been caught, by making simply every myth, fable or tale he has met with into a solar myth, from Jack-the-GiantKiller to Jonah, Cain, the Homeric poems, and so ad infinitum. Needless to say, this process often involves very far-fetched explanations. Thus the Royal Arms of England, "supported by the solar lion and the lunar unicorn," are made to express solar worship. We do not quite know what to make of the following curious statement (p. I73) :-

"The resemblance between the lives of the SunGod Phœbus Apollo and Jesus Christ, the central figure and Exemplar of the Christian religion, is striking. The circumstances of their birth were in many respects similar, in that they were born in comparative obscurity. . . . For a while Phoebus Apollo hid his greatness in a beggar's garb. ... This mode of existence was in every way similar to the life of Christ. . . . Although the Sun-God's death at nightfall is ignominious, akin in this respect to the crucifixion, still its predominant feature is one of glory, and the reappearance of the triumphant sun after death is in every No. 2393, VOL. 96] way typical of the resurrection, thus portraying in a startling manner the completeness of the analogy between the lives of Christ and Apollo."

Has the author ever heard of Dupuis and his "Origine de tous les cultes"? Probably not, as he only quotes books written in the English language. But Dupuis in his voluminous work proved to his own satisfaction that the founder of the Christian religion had never existed: he was only a solar myth, identical with Bacchus, Osiris, and Hercules. It is safer to be cautious in drawing parallels between fact and fiction and in looking everywhere for solar myths. But all the same, even a critical reader will find much to interest him in the accounts of sun-worship and sun-myths given in this volume, not least in the numerous extracts from the publications of the United States Bureau of Ethnology. The book is beautifully illustrated with thirty plates taken from paintings or giving views of sun temples and worship.

\section{POCKET ENCYCLOPADIAS \\ OF PETROLEUM AND CHEMISTRY.}

(r) Petroleum Technologist's Pocket-Book. By Sir Boverton Redwood, Bart., and Arthur W. Eastlake. Pp. xxiv + 454. (London: Charles Griffin and Co., Ltd., I9I5.) Price 8s. $6 d$. net.

(2) The Chemists' Year-Book, 1915. Edited by F. W. Atack. Two vols. Vol. i., pp. 354. Vol. ii., pp. 355-9i4. (London and Manchester: Sherratt and Hughes, 19r5.) Price ros. $6 d$. net.

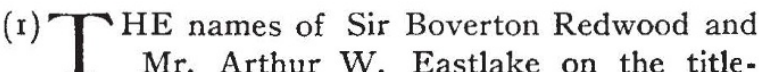
page of the "Petroleum Technologist's PocketBook" would alone be an ample guarantee that thoroughness of treatment and completeness of content would be found in its pages, and the work fully bears out the expectation arrived at. It is indeed a miniature edition of Sir Boverton Redwood's monumental work on petroleum, and in its 454 pages of pocket-book size contains more useful information, tables, and data referring to every branch of the mineral oil industry than it would be thought possible could be got into a portable form.

Starting with the origin and occurrence of petroleum in the earth's crust and its geographical distribution, prospecting for petroleum is next dealt with, and much useful information is given as to licences, mining leascs, and regulations in various parts of the world. 